\title{
Liquefaction mathematical analysis for improvement structures stability
}

\author{
Abdoullah Namdar, Azam Khodashenas Pelko, Asima Nusrath \\ Mysore University, India \\ ab_namdar@yahoo.com; sina_a_n@yahoo.com
}

\begin{abstract}
The stability of any structure is possible if foundation is appropriately designed. The Bandar abbas is the largest and most important port of Iran, with high seismicity and occurring strong earthquakes in this territory, the soil mechanical properties of different parts of city have been selected as the subject of current research. The data relating to the design of foundation for improvement of structure at different layer of subsoil have been collected and, accordingly, soil mechanical properties have been evaluated. The results of laboratory experiments can be used for evaluation of geotechnical characteristics of urban area for development a region with high level of structural stability. Ultimately, a new method for calculation of liquefaction force is suggested. It is applicable for improving geotechnical and structure codes and also for reanalysis of structure stability of previously constructed buildings.
\end{abstract}

KEYwORDs. Standard Code; Mathematical Concept; South Iran; Soil Mechanical Properties; Structure Foundation.

\section{INTRODUCTION}

I $\mathrm{n}$ recent years, a number of investigation on the existence of seismic hazard for the Iranian region has appeared [1-2]. Liquefaction due to earthquake is a big problem to be dealt with in engineering practice all over the world [3-4]. Effective foundations, including diverse types of piles and tanks, or other appropriate methods to improve ground qualities, including bad soil strata substitution and foundation treatment, are widely applied to resist the possible failure. Logical and rational evaluation of liquefaction potential, basic and essential work both for assessment of ground characters as encountering an earthquake and for corresponding reinforcement, is not very mature and satisfied up to now even after decades of hard work. The two most popular methods presently employed to assess liquefaction potential are all experimental or experiential [5-8]. There is different methods for supporting soft soil, it is reported that the shear strength increment of soft soil may affect the stability of soft ground treated with prefabricated vertical drains [9-16].

The Bandar Abbas city is playing very important function in Iran economic, this city placed in Hormozgan province [Fig.1]. This region should be safe and stable during earthquake or other natural disaster, for this purpose geotechnical site investigation come in picture for improving construction activities. Authors made an attempt to achieving best design of structure foundation in this territory.

\section{METHODOLOGY AND EXPERIMENTS}

$\mathrm{T}$ he experiments were conducted by collecting sample method directly in the Bandar Abbas city of Iran for Geotechnical Engineering site investigation. In these experiments, several data were analyzed to improve structure stability based on subsoil load sustainability. Calculations of safe bearing capacity of any specimens were made 
using the Terzaghi calculation method, and cohesion, angle of friction and unit weight were calculated. In all models depth of $1.5 \mathrm{~m}$ and width of $2.5 \mathrm{~m} * 2.5 \mathrm{~m}$ for foundation were assumed for calculation of safe bearing capacity.

Formulas for calculation of safe bearing capacity, suggested by Terzaghi, are presented below:

$$
\begin{aligned}
& q_{f}=1.3 C N_{c}+\gamma D N_{q}+0.4 \gamma B N_{\gamma} \\
& q_{n f}=q_{f}-\gamma D \\
& q_{s}=\left(\frac{q_{n f}}{f}\right)+\gamma D
\end{aligned}
$$

Also $N_{q}, N_{c}$ and $N_{\gamma}$ are the general bearing capacity factors which depend on 1) depth of footing, 2) shape of footing, 3) $\Phi$, (was used from suggestion by the Terzaghi calculation method) [17], and accordingly for assessing subsoil characteristics, collected data were interpreted and mathematical concept of wave theory used for accurate estimation of liquefaction force to improvement of structure stability at the time of earthquake in the Bandar Abbas of Iran.

\section{RESULTS AND DISCUSSION}

I he Bandar Abbas is capital city of Hormozgan province and it is located in Longitude: $56^{\circ} 15^{\prime} 0$ " E and Latitude: $27^{\circ} 12^{\prime} 0^{\prime \prime} \mathrm{N}$ with 15 meters elevation above sea level in the Persian Gulf (Fig. 1). This city situated on flat ground with an average altitude of $9 \mathrm{~m}(30 \mathrm{ft})$ above sea level. The nearest elevated areas are Mt. Geno, $17 \mathrm{~km}(11 \mathrm{mi})$ to the north, and Mt. Pooladi, $16 \mathrm{~km}(10 \mathrm{mi})$ to the northwest of the city. The closest river to Bandar Abbas is the River Shoor, which is rooted from Mt. Geno and pours into the Persian Gulf, $10 \mathrm{~km}(6 \mathrm{mi})$ east of the city.

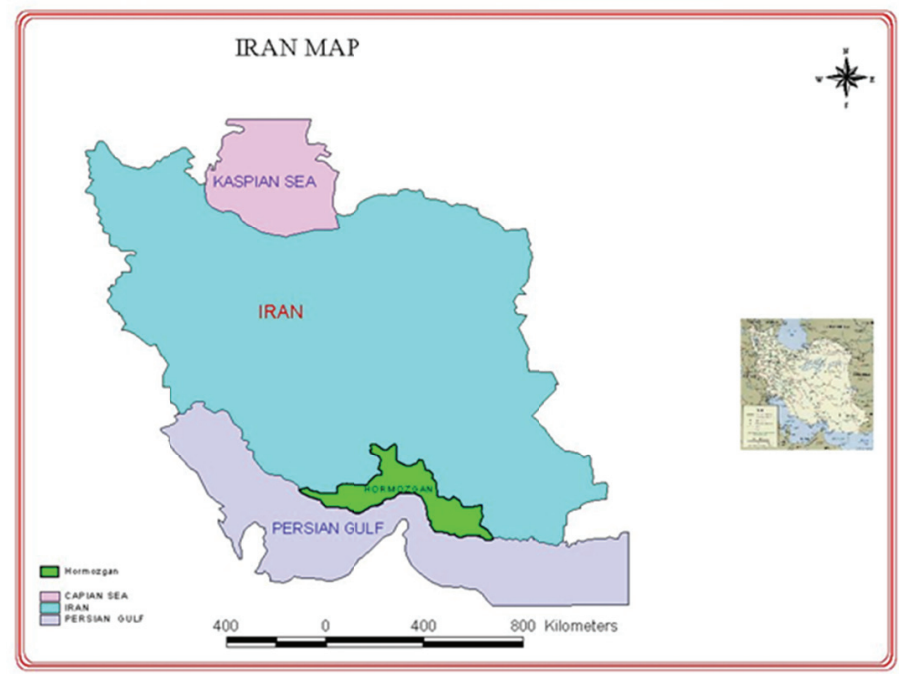

Figure 1: Bandar Abbas map of Iran placed in Hormozgan province in close to Persian Gulf.

The water table was found very high and it was shown to have a high effect on the subsoil stability and soil mechanical properties, which controlling structure stability. The soil angle of friction, cohesion, unit weight have been obtained through the geotechnical site investigation and the safe bearing capacity calculated by adopting Terzaghi calculation method. The angle of friction in different depth and place in the subsoil are between 29-33 degree, and soil cohesion (C) not excess of $11\left(\mathrm{kN} / \mathrm{m}^{2}\right)$ and the soil unit weight $(\gamma)$ is vary from 15.5 to $18.3\left(\mathrm{kN} / \mathrm{m}^{3}\right)$ (Figs. 2-3 and Tab. 1).

The local shear failure generally occurs in loose sand while general shear failure occurs in dense sand, when $\Phi<28^{\circ}$ local shear failure may be assumed, for $\Phi>36^{\circ}$, the general shear failure may be assumed, in this investigation the subsoil is loose. Tab.1 indicated that based on soil angle of friction that there is may local shear failure or general shear failure occur but based on unit weight it could predict that local shear failure will occur. The cohesion less subsoil of case study indicated that there is place of developing liquefaction in some area of city with presence of underground water near the surface. This work draw attention to the importance of designing foundation and improvement method, it is affective with structure stability. 


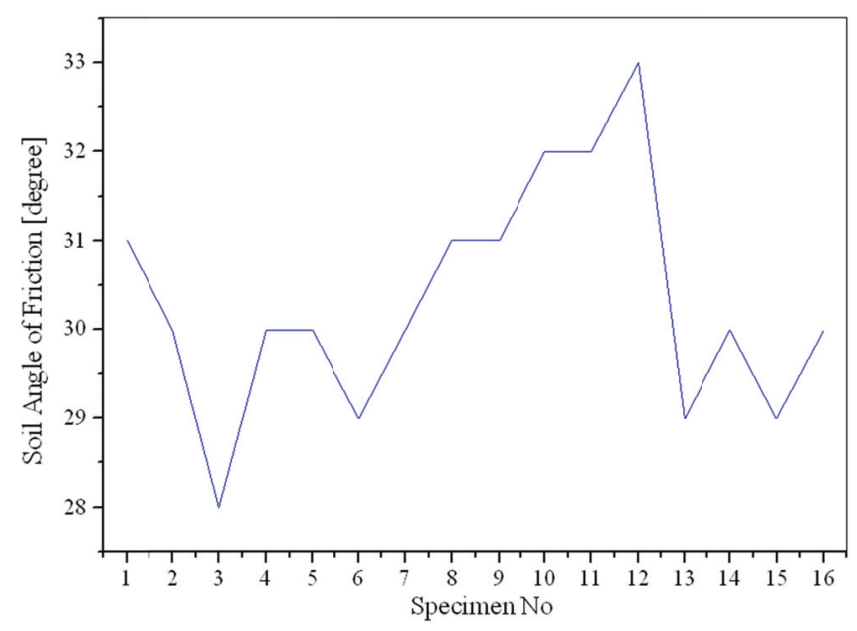

Figure 2: Angle of friction [degree] vs Model No.

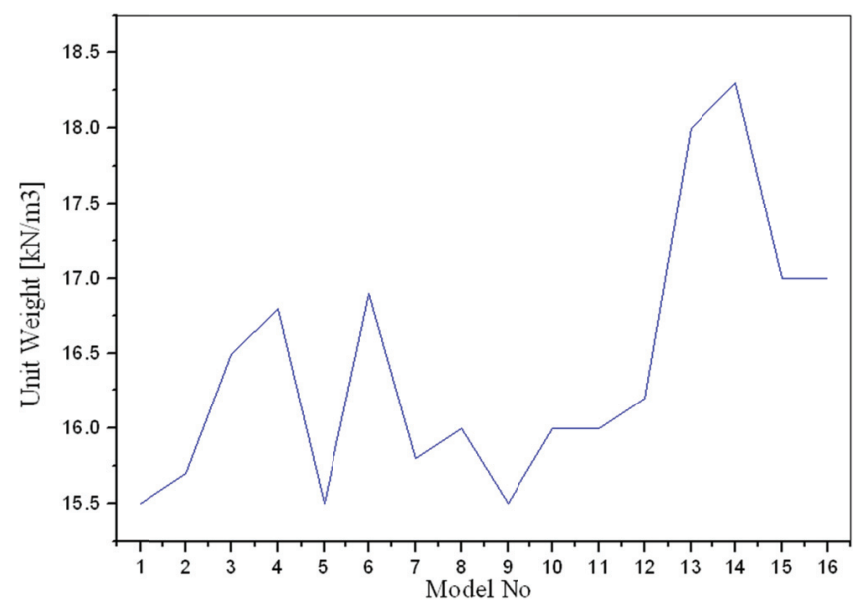

Figure 3: Unit Weight $\left[\mathrm{kN} / \mathrm{m}^{3}\right]$ vs Model No.

\begin{tabular}{|c|c|c|c|c|c|c|c|}
\hline $\begin{array}{c}\text { Specimen } \\
\text { No }\end{array}$ & $\begin{array}{c}\text { Specimen } \\
\text { No }\end{array}$ & $\begin{array}{c}\text { Depth of } \\
\text { Investigation } \\
{[\mathrm{m}]}\end{array}$ & $\begin{array}{l}\Phi \\
{[0]}\end{array}$ & $\begin{array}{c}\mathrm{C} \\
{\left[\mathrm{kN} / \mathrm{m}^{2}\right]}\end{array}$ & $\begin{array}{c}\gamma \\
{\left[\mathrm{kN} / \mathrm{m}^{3}\right]}\end{array}$ & $\begin{array}{l}\text { S. B. C } \\
{\left[\mathrm{kN} / \mathrm{m}^{2}\right]}\end{array}$ & $\begin{array}{l}\text { M.S.L } \\
{[\mathrm{kN}]}\end{array}$ \\
\hline \multirow{4}{*}{1} & 1 & 2 & 31 & 0 & 15.5 & 338.55 & 2115.91 \\
\hline & 2 & 4 & 30 & 0 & 15.7 & 295.42 & 1846.39 \\
\hline & 3 & 6 & 28 & 8 & 16.5 & 368.32 & 2301.98 \\
\hline & 4 & 10 & 30 & 7 & 16.8 & 428.96 & 2681.00 \\
\hline \multirow{2}{*}{2} & 5 & 2 & 30 & 0 & 15.5 & 291.66 & 1822.86 \\
\hline & 6 & 8 & 29 & 11 & 16.9 & 455.96 & 2849.74 \\
\hline \multirow{4}{*}{3} & 7 & 2 & 30 & 0 & 15.8 & 297.30 & 1858.15 \\
\hline & 8 & 4 & 31 & 0 & 16 & 349.47 & 2184.17 \\
\hline & 9 & 8 & 31 & 10 & 15.5 & 516.43 & 3227.68 \\
\hline & 10 & 12 & 32 & 0 & 16 & 397.87 & 2486.67 \\
\hline \multirow{2}{*}{4} & 11 & 2 & 32 & 0 & 16 & 397.87 & 2486.67 \\
\hline & 12 & 10 & 33 & 0 & 16.2 & 451.85 & 2824.03 \\
\hline 5 & 13 & 7 & 29 & 3 & 18 & 354.27 & 2214.21 \\
\hline 6 & 14 & 5 & 30 & 6 & 18.3 & 441.07 & 2756.66 \\
\hline 7 & 15 & 1 & 29 & 0 & 17 & 291.89 & 1824.31 \\
\hline 8 & 16 & 1 & 30 & 0 & 17 & 319.88 & 1999.27 \\
\hline
\end{tabular}

Table 1: Experiments results of soil mechanical properties in Bandar Abbas of Iran. 
It can be explained that the amplification of the earthquake motion through soft subsoil in Bandarabbas (up to $12 \mathrm{~m}$ depth) could created of more affect on structure stability and appearing of differential settlement and considerably reduction of the bearing capacity. There is strong earthquake code [Iran 2800 Code] for seismic resistant design of structure, but in practical during site geotechnical analysis, Poisson ratio and modulus elasticity have been assumed, this is caused mistake in structure seismic design. It may be suggested that obtain of Poisson ratio and modulus elasticity based on soil mechanical properties through the shaking table for simulation seismic force may be applied on structure. The earthquake should did not cause any significant damages to buildings and structures in the region. There is no approved mapping macroseismic for accurate structure design for earthquake resistance, and it should determine for each project on a case-by-case basis.

The structure shall be designed to withstand without collapse and maintain acceptable soil foundation bearing capacity after the seismic events. For the damage limitation it is required to provide structure and geotechnical suitable seismic code for this particular territory not one code for the whole of the country, the local code may be result of the long term research project conducted by local university and local civil engineering society and it should be approved by International Civil Engineering Society as well as the government authority at ministerial level, it is clear that such research activity give better and update knowledge to civil engineering community and lead to enhancement of structure seismic design. It should be noted that, for new code comprehensive information on soil dynamic properties is essential step.

Most of structures in this region are unprepared for earthquakes and also there is important to consider developing suitable code for protecting life and mitigation of damage from an earthquake event. A new code has to develop for very good representation of accelerations, velocities and displacements for sites to better assessing geomorphology of region and developing site stress strain guide map instant of only producing of earthquake risk map. Earthquakes in Bandar abbas can be considered in high consequence events. This territory has not captured sufficient near-field strong motion data to develop conventional (empirical) attenuation seismic models in data collection it is also needed to find correlation between soil mineralogy and propagate seismic force and its affect on the structure stability.

There is no geotechnical characteristic similarity in the whole of the country, and it could be concluded that during an earthquake, seismic waves with several characteristics could be developed and it is affected to the structures based on site geology and structures position, it is important to accurate analysis of site geological characteristics before establishing code, in this regard different theories could be accepting for developing seismic wave. It is important to mention that due to geological characteristics of subsoil during the earthquake, liquefaction occur and in this investigation wave theory should be employee for analysis of liquefaction force in presence of seismic force.

There is a method of calculating wave forces on piles [18],

$$
F=0.5 \rho D C_{d} U|U|+0.25 \rho \pi D^{2} C_{m} \frac{d u}{d t}
$$

where

$\mathrm{F} \quad=$ Force

$\varrho \quad=$ Density of fluid

$\mathrm{D} \quad=$ Diameter of pile

$\mathrm{C}_{\mathrm{d}} \quad=$ Drag coefficient

$\mathrm{C}_{\mathrm{m}} \quad=$ Inertia coefficient

To better understanding of seismic force on structure foundation the force required to be investigated in two parts one is velocity and the second is acceleration, and also the force maxima $\mathrm{p}(\mathrm{F})$ is more difficult to calculate but a formula presented for obtaining that [19-21].

$$
\mathrm{P}(\mathrm{F})=\frac{\mu(\mathrm{F})}{\int_{0}^{\infty} \mu(\mathrm{F}) \mathrm{dF}}
$$

where

$\mathrm{P}(\mathrm{F}) \quad=$ Force maxima

$\mu(\mathrm{F}) \quad=$ Extreme force rate density

There is presented wave spectrum, in terms of velocity, acceleration and force for analysis of wave characteristics [22].

$$
\text { Velocity Spectrum } S_{u}(f)=4 \pi^{2} f^{2} \frac{\cosh ^{2}(k(z+d))}{\sinh ^{2}\left(k_{d}\right)} S_{\eta}(f)
$$


Accelleration Spectrum $S_{a}(f)=16 \pi^{4} f^{4} \frac{\cosh ^{2}(k(z+d))}{\sinh ^{2}\left(k_{d}\right)} S_{\eta}(f)$

Force Spectrum $S_{F}(f)=\frac{8}{\pi} K_{d}^{2} Q_{u}^{2} S_{u}(f)+K_{i}^{2} S_{a}(f)$

where

$\mathrm{f} \quad=$ Sectional force on pile

$\mathrm{k} \quad=$ Number of wave

$\mathrm{z} \quad=$ Half length of wave

$\mathrm{d}=$ Depth of liquid

$S_{\eta}(f)=$ Wave spectrum

$K_{d} \quad=0.5 \varrho \mathrm{D} \mathrm{C}_{\mathrm{d}}$

$Q_{u} \quad=$ Horizontal velocity

$K_{i} \quad=\rho\left(\frac{\pi D^{2}}{4}\right) C_{m}$

All formula are presented above could be applied for understanding liquefaction force is subjected to structure foundation at the time of an earthquake. In structure stability not only earthquake force should be calculated it is essential to analysis of wave force created by liquid soil and applied on structure foundation. The force maxima, velocity, acceleration and force in liquefied subsoil could be calculated using Eqs 4-8. Tab.1 and Figs. 2-3 indicated the soil mechanical properties of the region. Based on data presented in Tab. 1 and using Eqs. 4-8, could finalize that the site geological structure will affect on the length, depth, number and spectrum of wave in the liquefied subsoil, and due to changing soil mechanical properties liquefaction magnitude fluctuate. This investigation can be leads to develop a hypothesis for mathematically considering wave characteristics in liquefied subsoil.

\section{CONCLUSION}

$\checkmark$ The result revealed that there is need of establishing better geotechnical code as well as seismic map zoning for improvement of structure have been constructed previously without considering geotechnical site investigation.

$\checkmark$ For analysis of soil mechanical stability need of accurate mathematical modeling for better understanding of soil dynamic properties.

$\checkmark$ The local code may be developed through the long term research project conducted by local university or local civil engineering society and it should be approved by International Civil Engineering Society.

$\checkmark$ In foundation seismic design it is require analysis of wave forces created by liquid soil based on wave theory along with earthquake force.

$\checkmark$ The site geological structure will affect on the length, depth, number, spectrum, velocity and acceleration of wave in liquefied subsoil.

\section{REFERENCES}

[1] A. Shafiee, A. Azadi, Journal of Asian Earth Sciences, 29 (2007)105.

[2] G. G. Amiri, R. Motamed, R. Hashemi, H. R. Nouri, In: ICE, Geotechnical Engineering, 159 (2006) 275.

[3] J. P. Bardet, M. Kapuskar, Journal of Geotechnical Engineering, 119(3) (1993) 543.

[4] A. King Stephanie, S. Kiremidjian Anne, H. Law Kincho, In: Conference on Natural Disaster Reduction, (1996) 123.

[5] R. O. Davis, J. B. Berrill, Geotechnique, 48(2) (1998) 289.

[6] D. Sam Liyanapathirana, H.G. Poulos, Soil Dynamics and Earthquake Engineering, 24(11) (2004) 867.

[7] John M. Ferritto, Journal of the Technical Councils of ASCE: Proceedings of the ASCE, 103(1) (1977) 65.

[8] Felix Y. Yokel, R. Dobry, David J. Powell, Richard S. Ladd, Microstructural Science, 2 (1980) 571. 
[9] R. Peck, B. Deep, In: $7^{\text {th }}$ ICSMKFE. State-of-the-Art-Volume, Mexico City, (1969) 225.

[10] G. W. Clough, T. D. O’Rourke, In: Design and Performance of Earth Retaining Structure. ASCE Special conference Ithaca New York, (1990) 439.

[11] O.U. Chang-yu, Lai Chang-her, Can. Geotech. J., 31 (1994) 204.

[12] P. T. Brown, Computers and Geotech, 1(3) (1995) 8.

[13] H.-W. Ying, X.-Y. Xie, K.-H. Xie, Journal of Building Structures, 20(4) (1999) 59.

[14] R.-L. Wei, Chinese Journal of Geotechnical Engineering, 19(6) (1997) 88.

[15] J.-L. Yu, X-N. Gong, China Civil Engineering Journal, 35(4) (2002) 86.

[16] Y. Guanbao, G. Yongfa, EJGE, 15A (2010).

[17] B. C. Punmia, Soil Mechanics and Foundations, Madras (1988).

[18] J. R. Morison et al., Petrol. Trans, AIME, 189 (1950) 149.

[19] C. C. Tung, J. Eng. Mech. Div., ASCE, 100 (1974) 873.

[20] V. J. Cardone et al., J. Petrol. Tech., 28 (1976) 385.

[21] R. G. Tickell, The Structural Engineer, 55 (1977) 209.

[22] L. E. Borgman, In: Offshore Tech. Conf., Houston, (1969) 721.

\section{NOMENCLATURE}

\begin{tabular}{|c|c|}
\hline$\Phi[0]$ & $=$ Friction Angle \\
\hline $\mathrm{C}\left[\mathrm{kN} / \mathrm{m}^{2}\right]$ & $=$ Soil Cohesion \\
\hline OMC \% & $=$ Optimum Moisture Content $\%$ \\
\hline S.B.C $\left[\mathrm{kN} / \mathrm{m}^{2}\right]$ & $=$ Safe Bearing Capacity \\
\hline$\gamma\left[\mathrm{kN} / \mathrm{m}^{3}\right]$ & $=$ Unit Weight \\
\hline$\mu$ & $=$ Poisson ratio \\
\hline $\mathrm{E}_{\mathrm{s}}$ & $=$ Modulus Elasticity $\left[\mathrm{kN} / \mathrm{m}^{2}\right]$ \\
\hline $\mathrm{f}$ & $=$ Soil Safety Factor \\
\hline M.S.L & $=$ Max Safe Load $[\mathrm{kN}]$ \\
\hline $\mathrm{F}$ & $=$ Force \\
\hline$\varrho$ & $=$ Density of fluid \\
\hline $\mathrm{D}$ & $=$ Diameter of pile \\
\hline $\mathrm{C}_{\mathrm{d}}$ & $=$ Drag coefficient \\
\hline $\mathrm{C}_{\mathrm{m}}$ & $=$ Inertia coefficient \\
\hline $\mathrm{p}(\mathrm{F})$ & $=$ Force maxima \\
\hline$\mu(\mathrm{F})$ & $=$ Extreme force rate density \\
\hline $\mathrm{f}$ & $=$ Sectional force on pile \\
\hline $\mathrm{k}$ & $=$ Number of wave \\
\hline z & $=$ Half length of wave \\
\hline d & $=$ Depth of liquid \\
\hline$S_{\eta}(f)$ & $=$ Wave spectrum \\
\hline$K_{d}$ & $=0.5 \varrho \mathrm{D} \mathrm{C}_{\mathrm{d}}$ \\
\hline$Q_{u}$ & $=$ Horizontal velocity \\
\hline$K_{i}$ & $=\rho\left(\frac{\pi D^{2}}{1}\right) C_{m}$ \\
\hline
\end{tabular}

